\title{
SUSTAIN drilling at Surtsey volcano, Iceland, tracks hydrothermal and microbiological interactions in basalt 50 years after eruption
}

\author{
Marie D. Jackson ${ }^{1}$, Magnús T. Gudmundsson ${ }^{2}$, Tobias B. Weisenberger ${ }^{3}$, J. Michael Rhodes ${ }^{4}$, \\ Andri Stefánsson ${ }^{2}$, Barbara I. Kleine ${ }^{2}$, Peter C. Lippert ${ }^{1}$, Joshua M. Marquardt ${ }^{1}$, Hannah I. Reynolds ${ }^{2}$, \\ Jochem Kück ${ }^{5}$, Viggó T. Marteinsson ${ }^{6,7}$, Pauline Vannier ${ }^{6}$, Wolfgang Bach ${ }^{8}$, Amel Barich ${ }^{3,9}$, \\ Pauline Bergsten $^{6,10}$, Julia G. Bryce ${ }^{11}$, Piergiulio Cappelletti ${ }^{12}$, Samantha Couper ${ }^{1}$, \\ M. Florencia Fahnestock ${ }^{11}$, Carolyn F. Gorny ${ }^{2}$, Carla Grimaldi ${ }^{12}$, Marco Groh ${ }^{5}$, Ágúst Gudmundsson ${ }^{13}$, \\ Ágúst T. Gunnlaugsson ${ }^{2}$, Cédric Hamlin ${ }^{14}$, Thórdís Högnadóttir ${ }^{2}$, Kristján Jónasson ${ }^{15}$, \\ Sigurdur S. Jónsson ${ }^{3}$, Steffen L. Jørgensen ${ }^{14}$, Alexandra M. Klonowski ${ }^{7}$, Beau Marshall ${ }^{16}$, \\ Erica Massey ${ }^{2}$, Jocelyn McPhie ${ }^{17}$, James G. Moore ${ }^{18}$, Einar S. Ólafsson ${ }^{2}$, Solveig L. Onstad ${ }^{14}$, \\ Velveth Perez $^{2,15}$, Simon Prause ${ }^{3}$, Snorri P. Snorrason ${ }^{19}$, Andreas Türke ${ }^{6}$, James D. L. White ${ }^{20}$, and \\ Bernd Zimanowski ${ }^{21}$ \\ ${ }^{1}$ Department of Geology and Geophysics, University of Utah, Salt Lake City, Utah, USA \\ ${ }^{2}$ Nordvulk, Institute of Earth Sciences, University of Iceland, Reykjavík, Iceland \\ ${ }^{3}$ ÍSOR, Iceland GeoSurvey, Reykjavík, Iceland \\ ${ }^{4}$ Department of Geosciences, University of Massachusetts, Amherst, Massachusetts, USA \\ ${ }^{5}$ Helmholtz Centre Potsdam, GFZ German Research Centre for Geosciences, Potsdam, Germany \\ ${ }^{6}$ Matís, Exploration \& Utilization of Genetic Resources, Reykjavík, Iceland \\ ${ }^{7}$ Faculty of Food Science and Nutrition, University of Iceland, Reykjavík, Iceland \\ ${ }^{8}$ Department of Geosciences and MARUM, University of Bremen, Bremen, Germany \\ ${ }^{9}$ Geothermal Research Cluster (GEORG), Reykjavik, Iceland \\ ${ }^{10}$ Faculty of Life and Environmental Sciences, University of Iceland, Reykjavík, Iceland \\ ${ }^{11}$ University of New Hampshire, Durham, New Hampshire, USA \\ ${ }^{12}$ Dipartimento di Scienze della Terra, dell'Ambiente e delle Risorse (DiSTAR), \\ University FEDERICO II, Naples, Italy \\ ${ }^{13}$ Jarðtaeknistofan, (GEOICE Geological Services Ltd), Hafnarfjörður, Iceland \\ ${ }^{14}$ K.G. Jebsen Centre for Deep Sea Research, Department of Earth Science, \\ University of Bergen, Bergen, Norway \\ ${ }^{15}$ Collections and Systematics Department, Icelandic Institute of Natural History, Gardabaer, Iceland \\ ${ }^{16}$ DOSECC Exploration Services, Salt Lake City, Utah, USA \\ ${ }^{17}$ School of Natural Sciences, University of Tasmania, Hobart, Australia \\ ${ }^{18}$ U.S. Geological Survey, Menlo Park, California, USA \\ ${ }^{19}$ Verkís Consulting Engineers, Reykjavík, Iceland \\ ${ }^{20}$ Geology Department, University of Otago, Dunedin, New Zealand \\ ${ }^{21}$ Institut für Geographie und Geologie, Universität Würzburg, Würzburg, Germany \\ Correspondence: Marie D. Jackson (m.d.jackson@utah.edu)
}

Received: 22 October 2018 - Revised: 3 March 2019 - Accepted: 14 March 2019 - Published: 12 June 2019

Abstract. The 2017 Surtsey Underwater volcanic System for Thermophiles, Alteration processes and INnovative concretes (SUSTAIN) drilling project at Surtsey volcano, sponsored in part by the International Continental Scientific Drilling Program (ICDP), provides precise observations of the hydrothermal, geochemical, geomagnetic, and microbiological changes that have occurred in basaltic tephra and minor intrusions since explosive and 
effusive eruptions produced the oceanic island in 1963-1967. Two vertically cored boreholes, to 152 and $192 \mathrm{~m}$ below the surface, were drilled using filtered, UV-sterilized seawater circulating fluid to minimize microbial contamination. These cores parallel a $181 \mathrm{~m}$ core drilled in 1979. Introductory investigations indicate changes in material properties and whole-rock compositions over the past 38 years. A Surtsey subsurface observatory installed to $181 \mathrm{~m}$ in one vertical borehole holds incubation experiments that monitor in situ mineralogical and microbial alteration processes at $25-124^{\circ} \mathrm{C}$. A third cored borehole, inclined $55^{\circ}$ in a $264^{\circ}$ azimuthal direction to $354 \mathrm{~m}$ measured depth, provides further insights into eruption processes, including the presence of a diatreme that extends at least $100 \mathrm{~m}$ into the seafloor beneath the Surtur crater. The SUSTAIN project provides the first time-lapse drilling record into a very young oceanic basaltic volcano over a range of temperatures, $25-141{ }^{\circ} \mathrm{C}$ from 1979 to 2017, and subaerial and submarine hydrothermal fluid compositions. Rigorous procedures undertaken during the drilling operation protected the sensitive environment of the Surtsey Natural Preserve.

\section{Introduction}

In late summer 2017, International Continental Scientific Drilling Program (ICDP) expedition 5059, the Surtsey Underwater volcanic System for Thermophiles, Alteration processes and INnovative Concretes (SUSTAIN) project (http: //surtsey.icdp-online.org, last access: 30 March 2019), drilled three cored boreholes through the basaltic tuff, tephra, and minor intrusions of Surtsey volcano, an oceanic island on the insular shelf $32 \mathrm{~km}$ from the south coast of Iceland. Surtsey was created by explosive and effusive eruptions from 1963 to 1967 in the Vestmannaeyjar archipelago, a young volcanic system that marks the offshore, southward-propagating tip of Iceland's SE rift zone (Einarsson, 2008; Jakobsson et al., 2009) (Fig. 1). The island emerged from a seafloor depth of about $130 \mathrm{~m}$ below sea level (b.s.l.) (Thórarinsson et al., 1964; Thors and Jakobsson, 1982; Jakobsson et al., 2009) (Fig. 1) and eventually attained a height of $150 \mathrm{~m}$ above sea level (a.s.l.). Explosive eruptions followed by lava flows produced approximately $1 \mathrm{~km}^{3}$ of eruptive products at the termination of activity in June 1967 (Thórarinsson et al., 1964; Thórarinsson, 1967, 1969). Progressive geochemical changes in the eruptive units over the 3.5 years of activity suggest magmatic mixing of depleted ridge basalt with ponded, enriched alkali basalt at the propagating ridge axis (Schipper et al., 2015, 2016).

A $181 \mathrm{~m}$ deep, cored borehole first explored subsurface processes at Surtsey in 1979, through the rim of Surtur, the eastern tephra cone. In early papers this was Surtur I and the western cone was Surtur II. Surtur II was subsequently given the name Surtungur (e.g., Baldursson and Ingadóttir, 2007). The top of the core is approximately $58 \mathrm{~m}$ a.s.l. (Fig. 1). Investigations of the core described volcanic structures above and below sea level, the thermal system, and the composition and alteration of basaltic tephra. The lithified volcanic tephra, mostly lapilli tuff, is composed of glass, crystals, and authigenic mineral cements (Jakobsson and Moore, 1982, 1986). Temperatures and fluid compositions in the 1979 borehole have been monitored since 1980 (Jakobsson et al., 2000;
Marteinsson et al., 2015). These reveal differential cooling rates in the basaltic deposits (Fig. 2).

Surtsey forms a natural reserve and World Heritage Site of the United Nations Educational, Scientific and Cultural Organization (UNESCO) (https://whc.unesco.org/en/list/1267, last access: 30 March 2019), which "has been protected since its birth, providing the world with a pristine natural laboratory" (Baldursson and Ingadóttir, 2007). Studies of primary biological succession on land provide a unique scientific record of colonization of basaltic lava and tephra by plants, animals, and marine organisms. Furthermore, initial results of 16S rDNA tag sequencing analysis of fluids extracted in 2009 from the submarine zone of the 1979 borehole contain unique sequences of bacteria, archaea, and viruses with icosahedral symmetry below a $140^{\circ} \mathrm{C}$ (1980) temperature maxima at $100 \mathrm{~m}$ depth below the ground surface (Marteinsson et al., 2015). These indicate methanomicrobia-related sequences at $172 \mathrm{~m}\left(54^{\circ} \mathrm{C}\right.$ in 2009$)$ and archaeoglobus-like sequences at $145 \mathrm{~m}\left(80^{\circ} \mathrm{C}\right.$ in 2009) (Fig. 2). The microbial life may be derived from the seafloor and, therefore, potentially indigenous to the submarine volcanic biosphere. Microbial habitats in the submarine Surtsey deposits could potentially represent a subsurface equivalent of the terrestrial colonization of Surtsey basalt, which has been systematically recorded over the past 50 years (Magnússon et al., 2014).

The goal of creating a time-lapse drill core record of basaltic deposits at Surtsey 50 years after eruption was first conceived in 2013 (Jackson et al., 2015; Witke, 2017). Four years of advance planning and preparation resulted in the acquisition of nearly $650 \mathrm{~m}$ of core from three boreholes that traverse the still-hot volcano by the SUSTAIN project, sponsored by the ICDP and other international partners. The proposed drilling targets were to (1) create a vertical cored borehole adjacent to the 1979 borehole to investigate the progress of geochemical, mineralogical, and hydrothermal processes in the basalt over the past 38 years (Figs. 2-4); (2) explore potential microbial interactions within the basalt that were not considered during 1979 drilling; (3) create an in situ laboratory, the Surtsey subsurface observatory, within the vertical borehole, dedicated to experiments within the diverse 

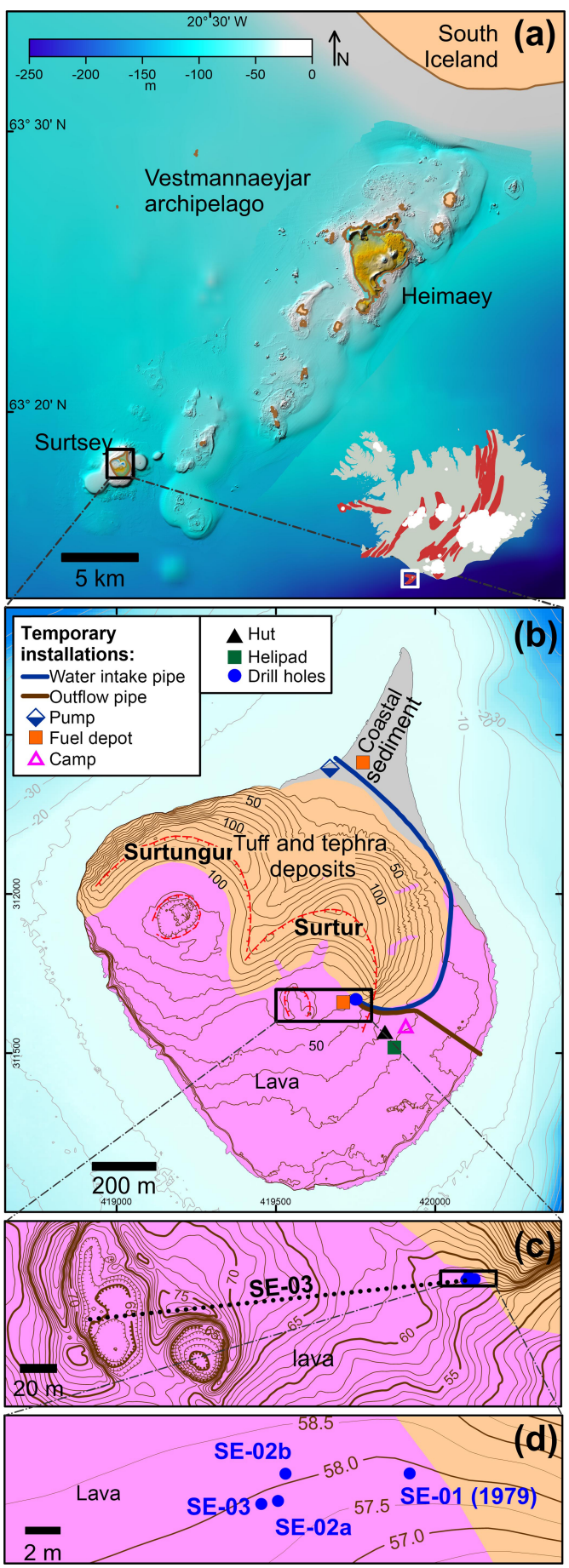

Figure 1. Maps showing drilling at Surtsey volcano, Iceland. (a) The Vestmannaeyjar volcanic archipelago at the southern offshore extension of the eastern Iceland rift zone (bathymetry: Icelandic Coast Guard, Hydrographic Department). The red elongated patches on the Iceland map show individual volcanic systems. (b) A simplified geological map of Surtsey (following Jakobsson, 2000) and temporary installations of the 2017 SUSTAIN drilling operation. The red dashed tick lines indicate crater rims. (c) Horizontal projection of the SE-03 (5059-1-D) cored borehole. (d) Wellhead locations: SE-01 (1979) and SE-02b, SE-02b, and SE-03 (or 50591-B, 5059-1-C, and 5059-1-D) (2017). zones of the hydrothermal system (Türke et al., 2019); and (4) further investigate the deep structure of the volcano with a cored borehole inclined below Surtur, the eastern crater, which could potentially intersect the pre-eruption seafloor (Fig. 5).

\section{Scientific objectives and societal benefits}

SUSTAIN investigations address three central questions. (1) How do explosive eruptions of oceanic volcanoes develop and produce potentially hazardous tephra clouds? (2) How do incipient oceanic volcanic islands develop hydrothermal systems, lithify, and stabilize themselves over time to resist incessant marine erosion? (3) How does life in its many forms inhabit and produce material changes in very young subsurface basaltic deposits? The interdisciplinary, collaborative studies of the drill cores, associated hydrothermal fluids, and incubation experiments in the subsurface observatory are

i. investigating geothermal processes and alteration rates as analogs for rapid changes in the material behavior of the young oceanic crust;

ii. describing how authigenic alteration of glass, olivine and plagioclase, palagonitization processes, and microbial influences record hydrothermal-microbial-basalt interactions over a range of temperatures and fluid compositions;

iii. exploring how processes of chemosynthetic life evolve in extreme temperature conditions;

iv. recording the macroscopic rock-physics properties of lithified lapilli tuffs as geological analogs for ancient Roman and modern seawater concretes; and

v. performing in situ experimental research in the Surtsey subsurface observatory to describe the short-term evolution of microbiological-seawater-rock interactions.

The scientific and societal benefits of the SUSTAIN project will result from

i. investigating explosive Surtseyan eruptive processes as a means to refine the predictions of hazards associated with the subaerial phases and rapid edifice growth of island-forming seafloor volcanoes;

ii. describing chemical, magnetic, and material changes in the Surtsey deposits produced by hydrothermalmicrobial-rock interactions, as a means to refine geophysical monitoring of thermal and chemical stimulation in hydrothermal reservoirs and the potential for fluid waste disposal and storage sites in pyroclastic rocks; and 

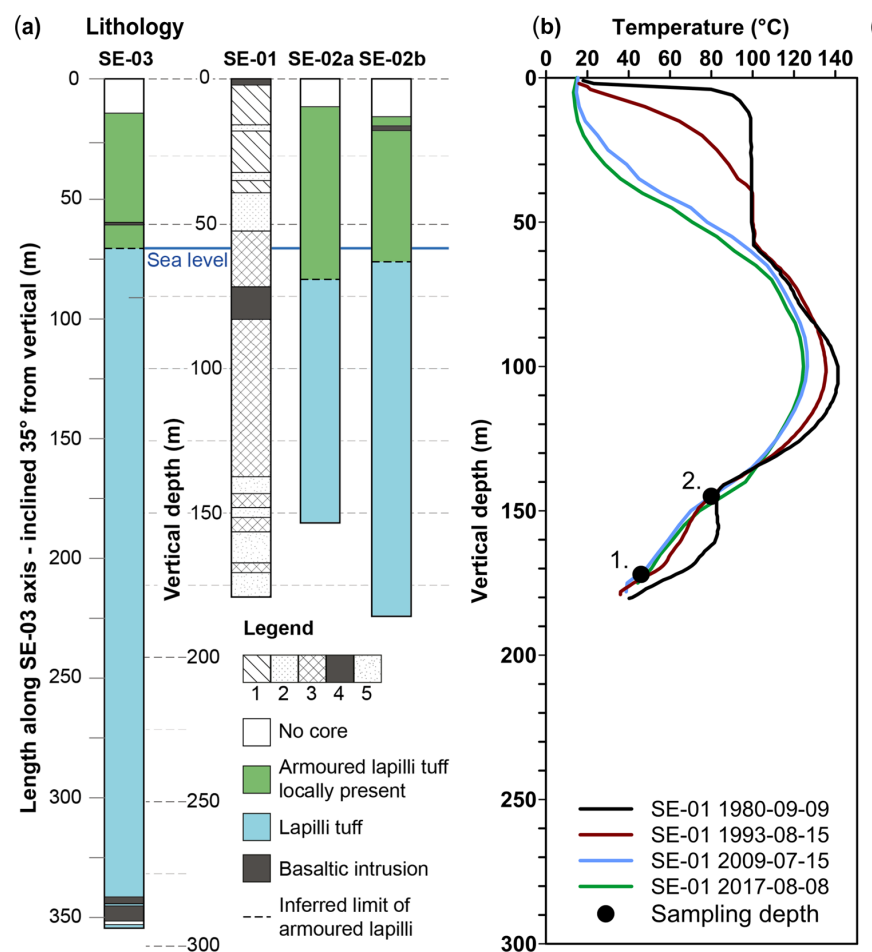

(c) Temperature $\left({ }^{\circ} \mathrm{C}\right)$

$0 \quad 20406080100120140$

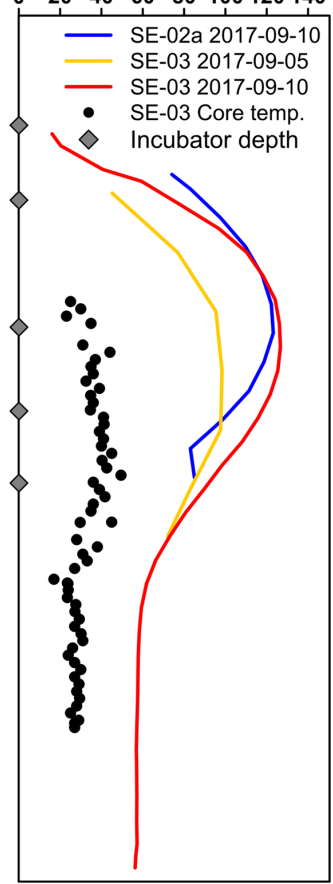

Figure 2. Comparisons of the 1979 and 2017 cored Surtsey boreholes. (a) Lithological logs. The 1979 core: SE-01 (following Jakobsson and Moore, 1982). (1) Weakly altered hyaloclastite, brown-black; (2) coarse and poorly graded hyaloclastite, black; (3) sound hyaloclastite, greyish-green; (4) basaltic intrusions and lava (at top), black; and (5) incoherent tephra. The 2017 simplified core logs: SE-02a, SE-02b, and SE-03 (following Weisenberger et al., 2019). (b) Borehole temperatures: SE-01 with 1980, 1993, 2009, and 2017 measurements, as well as 2009 microbiological samples $(1,2)$ (Jakobsson and Moore, 1982; Jakobsson et al., 2000; Marteinsson et al., 2015). (c) Borehole temperatures measured shortly after termination of drilling in SE-02b and SE-03 as well as depths of incubation experiments in SE-02b.

iii. determining the role of geochemical and biochemical processes in the development of zeolite and $\mathrm{Al}$ tobermorite mineral cements in basaltic tuff and transferring this information to reproductions of these cementitious fabrics in innovative pyroclastic rock concretes, cementitious barriers, and waste forms using reactive glass aggregates.

\section{Permitting and zero-impact drilling strategies}

Preparations for the zero-impact drilling operation on Surtsey required 2 years of logistical planning and permitting after ICDP funding was approved in 2015 (Jackson et al., 2015). Every effort was made to fully preserve the sensitive surface and subsurface environments of the Surtsey Nature Reserve and to follow all guidelines set by the Iceland Environment Agency and Surtsey Research Society to avoid any risk to the vegetation, birds, and sea life that inhabit the island and the marine preserve that surrounds it. This special protection has been in place since 1965, with amendments made in 2006 and 2011, to ensure that the island and its geological formations, flora, and fauna evolve without human intervention.
Four permits were required to carry out the drilling operation (Weisenberger et al., 2019). A Planning Agency (Skipulagsstofnun) decision allowed drilling to proceed without an environmental impact assessment. The Environment Agency (Umhverfisstofnun) issued a permit outlining requirements, as well as a license for drilling and construction of temporary facilities. Travel permits for individuals were issued separately. All equipment was cleaned before transport to Surtsey, ensuring that no seeds or organisms were brought to the island. Fuel barrels were stored on four layers of reinforced plastic sheeting and treated with utmost care. All waste, including human waste and cinders at the drill site and allterrain vehicle parking sites, were transported off-island. All traces of the operation were removed, except the wellheads. Entering bird nesting areas was prohibited before 15 August, and entering the peninsula was prohibited after 1 September. The South Iceland Health Inspectorate (Heilbrigðiseftirlit Suðurlands) issued a permit for running a camp, provisioning of food, and fulfilling hygiene requirements. The Vestmannaeyjar municipality also issued a permit to carry out the operation.

Some of the most challenging aspects of drilling on Surtsey involved the logistical difficulties of establishing and maintaining a camp and drilling operation on a remote is- 


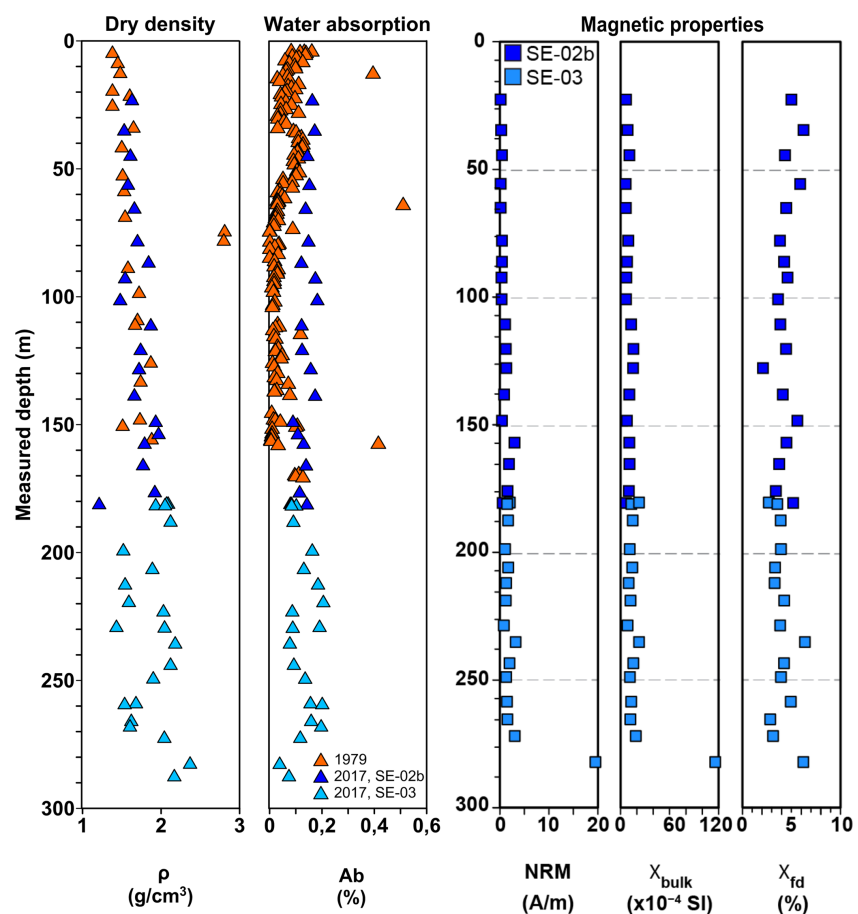

Figure 3. Material and magnetic measurements of Surtsey drill core samples. Dry density and water absorption (ASTM C97/C97M-18), 1979 SE-01 (Jakobsson and Moore, 1982; Oddsson, 1982), and 2017 samples and reference samples, SE-02b and SE-03 (Table S1). Magnetic properties, natural remanent magnetization (NRM), bulk magnetic susceptibility ( $\chi_{\text {bulk }}$, recorded as $\chi_{\mathrm{LF}}$ ), and frequencydependent magnetic susceptibility $\left(\chi_{\mathrm{fd}}\right)$ of 2017 reference samples, SE-02b and SE-03 (Table S2).

land that required strict environmental protection and relied almost solely on helicopter support. Logistical planning for drilling strategies, equipment organization, and packing required 3 months of dedicated effort at DOSECC Exploration Services, Salt Lake City, Utah, USA. Logistical planning to secure a functional camp while fulfilling safety and environmental requirements took place in Iceland. Drilling equipment was shipped from Portland, Oregon, USA, to Reykjavík; trucked to Porlákshöfn on the southern coast of Iceland; and transported to the eastern coast of Surtsey by the Iceland Coast Guard vessel, Pór. The Coast Guard Super Puma helicopter, TF LÍF, then flew about $63 \mathrm{t}$ of material, including the Atlas Copco CS-1000 drill rig disassembled into eight transportable components, and diesel, gas, and fresh water in 107 lifts to the drill, camp, and seawater pumping sites on 28-30 July (Weisenberger et al., 2019). Drilling took place from 7 August to 4 September. Demobilization with the Coast Guard vessel and TF LÍF took place from 10 to 12 September. At the termination of SUSTAIN activities the restoration of the island environment was approved as correctly implemented after inspection by the Environment Agency on 10 September. The 1979 Surtsey drill core and the 2017 SUSTAIN drill cores are archived at the Iceland Institute of Natural History.

The SUSTAIN drilling project has added several milestones to the record of drilling into oceanic basalt. Two vertical, cored boreholes (5059-1-B and 5059-1-C, also known as SE-02a and SE-02b) parallel the 1979 borehole (SE-01). These provide the first time-lapse record of drilling into very young basalt - with minimal live microbial contamination from seawater circulating fluids. A Surtsey subsurface observatory in borehole SE-02b offers the unprecedented opportunity to monitor "zero age" basalt without the expense and risk of a deep ocean operation. Five in situ incubation experiments were hung in perforated sections of an anodized aluminium casing installed from 38 to $161 \mathrm{~m}$ measured depth at $36-124^{\circ} \mathrm{C}$ at the end of activities in 2017 (Türke et al., 2019; Weisenberger et al., 2019). A third, inclined core borehole, SE-03, is the first to probe the deep submarine structure of a young Surtseyan volcano (Moore, 1985; White and Ross, 2011). The project thus provides a wealth of new information about the structure of the eruptive conduit and explosive eruption mechanics of Surtsey, the evolution of its hydrothermal system, the rates of cementing processes in basaltic glass systems, and the active record of basalt-microbial-seawater interactions that are thought to influence the abundance and diversity of life in the oceanic crust (Santelli et al., 2008).

\section{Drilling the 1979 cored borehole}

The 1979 borehole was cored in NQ $(47.6 \mathrm{~mm}$ core diameter) through the eastern crater of the volcano, until the bit became stuck at $176.5 \mathrm{~m}$ below the ground surface (Fig. 2) (Jakobsson and Moore, 1982, 1986). It was then completed in BQ (36.5 mm core diameter) to the total depth. Core recovery was very good $(97.9 \%)$ to $138 \mathrm{~m}$. Poor recovery and slow drilling progress occurred at 140.0-143.8, 148.5-150.6, $157.4-168.7$, and $170.5-180.1 \mathrm{~m}$, mainly in zones of poorly consolidated tephra (Fig. 6). Recurring disturbances of the offshore seawater intake about $0.5 \mathrm{~km}$ east of the drill site also caused drilling delays. Seawater was the circulating medium; no drilling mud was employed. Return fluids were flushed back to the ocean. The steel drill casing remains in the hole.

The stratigraphic zones of the volcano include lapilli tuff and basaltic intrusions from 14 to $58 \mathrm{~m}$ below the ground surface at steam temperatures $\left(100^{\circ} \mathrm{C}\right.$ in 1980$)$; a zone of tidal flux centered at $58 \mathrm{~m}$ (sea level); an $80 \mathrm{~m}$ section of highly altered lapilli tuff that includes the temperature maximum, $141^{\circ} \mathrm{C}$ (1980), of the hydrothermal system at $100-106 \mathrm{~m}$; and zones of weakly lithified tuff and unconsolidated tephra at $140-181 \mathrm{~m}$ at $40-89^{\circ} \mathrm{C}$ in 1980 (Jakobsson and Moore, 1982) (Fig. 2). Hydrothermal mineral assemblages and alteration rates of basaltic glass and olivine varied through these zones (Jakobsson and Moore, 1986). 

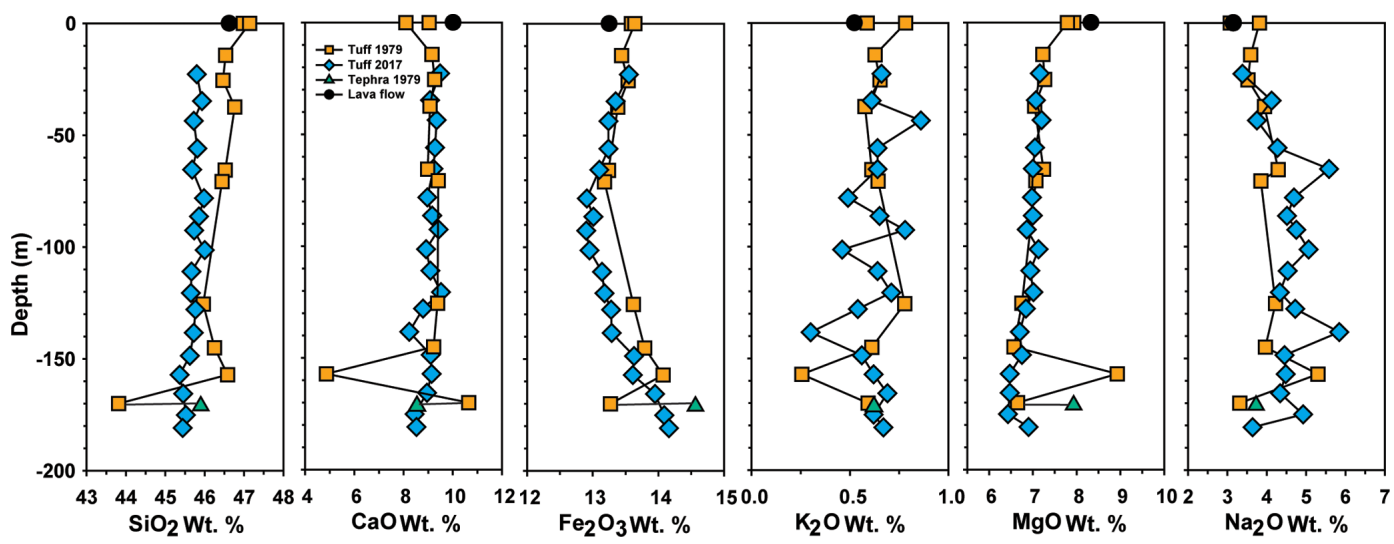

Figure 4. Whole-rock geochemical compositions, 1979 core archive, and 2017 SE-02b reference samples (Table S3) following the methods of Rhodes and Vollinger (2004).

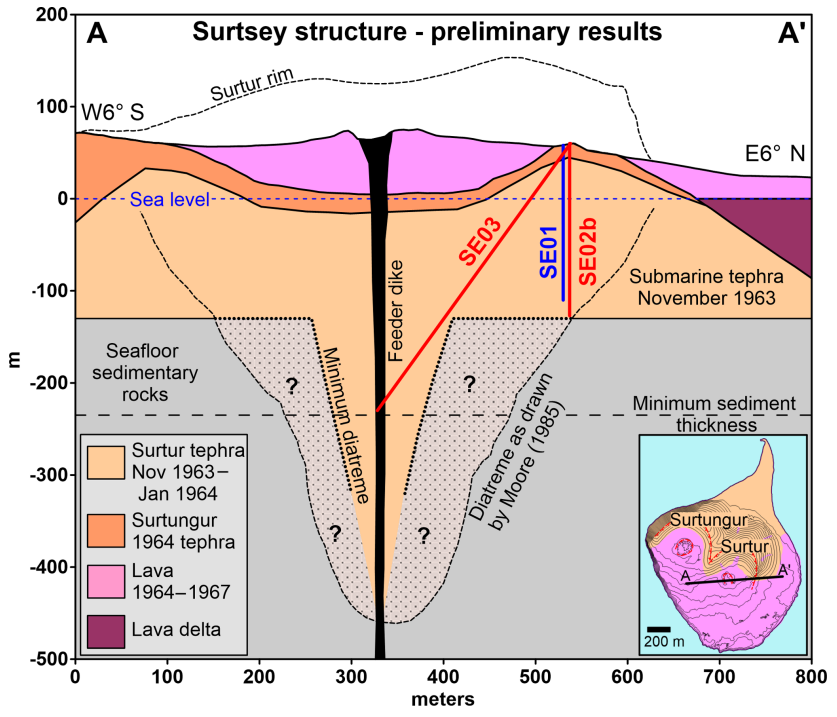

Figure 5. Structural sketch of Surtsey showing the minimum subsurface diatreme required to fit to the drilling results and the Moore (1985) hypothesis. The minimum thickness of marine sedimentary rock below the pre-eruption seafloor is $100 \mathrm{~m}$, based on seismic reflection results from Thors and Jakobsson (1982). The advance of basaltic lava flows in 1964-1967 produced the lava delta.

During the 1963-1964 explosive activity, intermittent tephra-finger jets and continuous uprush jets $100-250 \mathrm{~m}$ in diameter and 500-2000 $\mathrm{m}$ in height formed eruption columns up to $9 \mathrm{~km}$ high (Thórarinsson, 1967). Measurements of primary bedding, planar slump surfaces, and shear planes core, as well as fragments of indurated marine sediments and rounded exotic pebbles suggested a diatreme-like volcanic conduit produced by explosions that quarried and ejected pyroclastic debris and fragments of host rock from a depth of several hundred meters (Moore, 1985). This contrasts with an assumption of a shallow crater model for the volcano by earlier workers (Thórarinsson, 1967; Kokelaar, 1983), in

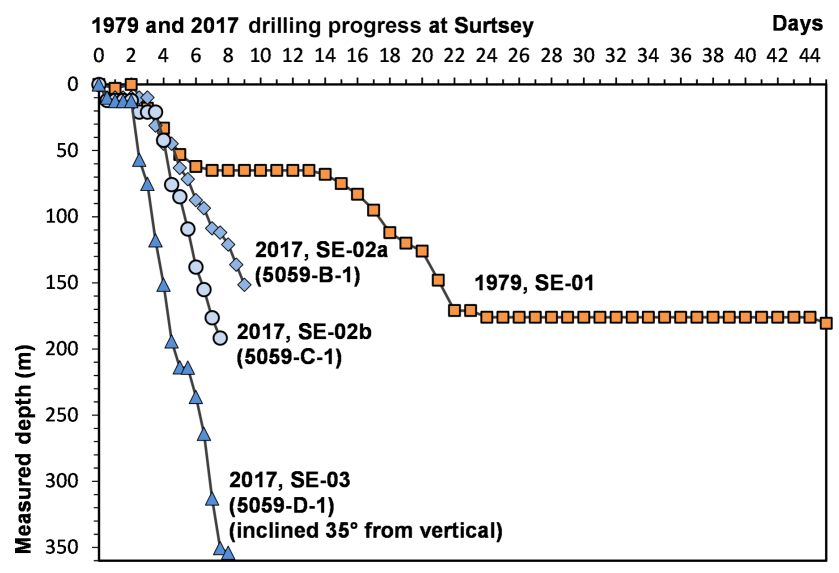

Figure 6. Rates of drilling progress in 1979 and 2017 (following Weisenberger et al., 2019).

which any diatreme that formed was narrow and left the preeruption seafloor mainly intact underneath the volcanic edifice (Fig. 5).

\section{Drilling the 2017 cored boreholes}

The opportunity to precisely quantify rates of change at Surtsey strongly influenced the decision to locate the 2017 SUSTAIN boreholes next to the 1979 borehole. The four wellheads, SE-01 (1979) and SE-02a, SE-02b, and SE-3 (2017), lie within a $10 \mathrm{~m}$ wide area on the ground surface of unconsolidated tephra on the southern flank of the Surtur tuff cone (Figs. 1c, d, 5). A detailed record of the drilling operation is given in Weisenberger et al. (2019).

Preparation of the drill site, installation of the offshore pumping system and water line, construction of the camp, Coast Guard boat and helicopter mobilization, helicopterassisted assembly of the drill rig, and rigging up took place 24 July-6 August 2017. Seawater circulating fluid was 
pumped $1.4 \mathrm{~km}$ from a submerged offshore pump anchored off the western coast of the northern peninsula (Fig. 1b). Drilling the first vertical borehole, SE-02a, began on $7 \mathrm{Au}$ gust using an Atlas-Copco CS-1000 rig (Adkins, 2018). The rig was mounted on a spinner base and anchored by HQ rods drilled into the basaltic lava substrate beneath about 1-2 m of tephra. Seawater was passed through a Pentek Big Blue $30 \mu \mathrm{m}$ cartridge filter and two AQUA4ALT WEDECO ultraviolet sterilization devices at the drill site to ensure minimal sediment and live microbial contamination of the recovered core; no mud products were employed. SE-02a was vertically pre-drilled with a $61 / 8 \mathrm{in} .(15.56 \mathrm{~cm})$ tricone rotary bit to a measured depth of $9.55 \mathrm{~m}$. A $41 / 2 \mathrm{in}$. $(11.43 \mathrm{~cm})$ HWT conductor casing (inner diameter $101.6 \mathrm{~mm}$ ) was installed to a casing shoe depth of $9.54 \mathrm{~m}$. Coring with an HQ3 bit (63.5 $\mathrm{mm}$ core diameter) extended to $151.57 \mathrm{~m}$ measured depth below the ground surface (or $93 \mathrm{~m}$ b.s.1.). Core recovery was about $97 \%$ overall. Continued problems with seawater supply to the drill site greatly slowed drilling progress (Fig. 6), and hole collapse occurred on 16 August below $46 \mathrm{~m}$ measured depth. The $43 \mathrm{HQ}$ drill rods and the bottom-hole assembly ( $4.14 \mathrm{~m}$ ) could not be extracted from the borehole, thereby preventing installation of the subsurface observatory. An extension to the casing and a flange were installed to $0.44 \mathrm{~m}$ above the ground surface.

A second vertical core, SE-02b, was then drilled from 19 to 26 August to create the borehole for the Surtsey subsurface observatory. After rotating the drill rig (and shack) on the spinner base, pre-drilling with a $61 / 8 \mathrm{in}$. $(15.56 \mathrm{~cm})$ tricone bit proceeded to approximately $13 \mathrm{~m}$ measured depth below the ground surface. A $41 / 2 \mathrm{in}$. (11.43 cm) HWT conductor casing was installed to a casing shoe depth of $12.74 \mathrm{~m}$, but subsequent problems required interventions that eventually resulted in a $14.40 \mathrm{~m}$ casing shoe depth. Drilling progress improved substantially relative to borehole SE-2a (Fig. 6), through installation of a $16000 \mathrm{~L}$ storage reservoir constructed of linked plastic totes on the northern peninsula. External pumps in tide pools on the western shoreline of the peninsula were managed continuously to transport seawater to this storage reservoir. The submersible pump was installed in one tote; it pumped the stored seawater $1.3 \mathrm{~km}$ to the drill site. Coring with an HQ3 bit reached a total depth of $191.64 \mathrm{~m}$ measured depth. A Florigel attapulgite product was employed to ensure stability in the top of the borehole, where fracture and collapse of the borehole walls occurred in SE-02a, and in poorly consolidated deposits below $140 \mathrm{~m}$ measured depth. Core recovery was $97 \%$ overall. This is the only hole surveyed with a geophysical downhole log (Fig. 7).

The 6061-T6 anodized aluminum alloy NQ casing (2 3/4 in. (69 mm) outer diameter, $21 / 4 \mathrm{in}$. (57 mm) inner diameter) of the Surtsey subsurface observatory was run into the borehole to a measured landing depth of $181.25 \mathrm{~m}$. The aluminum casing hangs freely inside the HWT conductor casing from the wellhead, and PVC centralizer tubes minimize contact between the aluminum casing and steel conductor casing (Türke et al., 2019; Weisenberger et al., 2019). A flange was installed to $0.21 \mathrm{~m}$ above reference ground height. Five perforated sections allow free fluid flow through the casing at specific depth intervals, which contain temperature loggers and perforated PEEK (polyetherketone) incubators attached to a Vectran rope hung from the wellhead. These were installed at 37.01-38.63 m $\left(36^{\circ} \mathrm{C}\right), 62.74-63.96 \mathrm{~m}\left(91^{\circ} \mathrm{C}\right), 106.11-107.33 \mathrm{~m}\left(124^{\circ} \mathrm{C}\right)$, $135.03-136.25 \mathrm{~m}\left(102^{\circ} \mathrm{C}\right)$, and $160.48-161.70 \mathrm{~m}\left(61^{\circ} \mathrm{C}\right)$ measured depth (Türke et al., 2019; Weisenberger et al., 2019) (Fig. 2c); the temperatures were measured in the SE01 borehole on 8 August 2017. A 2-year in situ incubation experiment designed to record rock-microbe-water interactions in basaltic glass granules melted from Surtsey lava and in olivine (Fo90) was installed 6 September 2017.

The SE-03 borehole, inclined $35^{\circ}$ from vertical in a $264^{\circ}$ azimuthal direction (Fig. 1c), was drilled from 28 August to 4 September with untreated seawater and occasional attapulgite mud. After rotating the drill rig on the spinner base, pre-drilling with a $61 / 8 \mathrm{in}$. $(15.56 \mathrm{~cm})$ tricone rotary bit extended to a measured depth of $12.6 \mathrm{~m}$. A $41 / 2 \mathrm{in}$. $(11.43 \mathrm{~cm})$ HWT conductor casing with a casing shoe depth of $11.91 \mathrm{~m}$ was cemented in place. Coring with an HQ3 bit continued to $213.9 \mathrm{~m}$, when the supply of HQ drill rods ran out. Coring continued with an NQ3 bit (43 mm core diameter) to a final inclined length of $354.05 \mathrm{~m}$ (Figs. 2, 5, 6). Core recovery was nearly $100 \%$ through the lapilli tuff but variable, 40-90\%, in basaltic intrusions within the zone below the crater. The NQ coring string was left in the hole as permanent casing, including the NQ3 bottom-hole assembly. An extension to the casing and a flange were installed to $0.48 \mathrm{~m}$ above the ground surface (measured length $0.59 \mathrm{~cm}$ ).

The SE-03 core traverses the deep Surtur vent structure and intrusions to a total vertical depth of $290 \mathrm{~m}$ and a horizontal distance approximately $203 \mathrm{~m}$ west of the wellhead (Fig. 1c). Dike intrusions occur in the lowermost $15 \mathrm{~m}$ of the core; the overlying deposits are entirely lapilli tuff (Fig. 2a). The SE-03 core thus traverses a diatreme that was excavated into seafloor sedimentary rock during the explosive phase of the Surtsey eruptions (Fig. 5). Lithic fragments ejected from the pre-eruptive seafloor occur in the lapilli tuff; there are also large blocks of seafloor sedimentary rock exposed on the subaerial tuff cone. The stratified sequence of volcaniclastic sedimentary rock is at least $100 \mathrm{~m}$ thick and the preeruption seafloor at about $130 \mathrm{mb}$.s.l. is draped by Surtsey pyroclasts close to the island (Jakobsson, 1982; Thors and Jakobsson, 1982; Jakobsson et al., 2009). However, no in situ deposits of the pre-eruption seafloor sedimentary rock were acquired by the either the 1979 or 2017 drilling projects. Preliminary analyses of the lapilli tuff from all three boreholes are examining volcanic fabrics, layering characteristics, the structural features of slump and shear planes (Moore, 1985), and the compositions and volumetric concentrations of xenoliths from seafloor sedimentary rock and ice-rafted glacial debris (Alexandersson, 1972; Reynisson and Jakobs- 

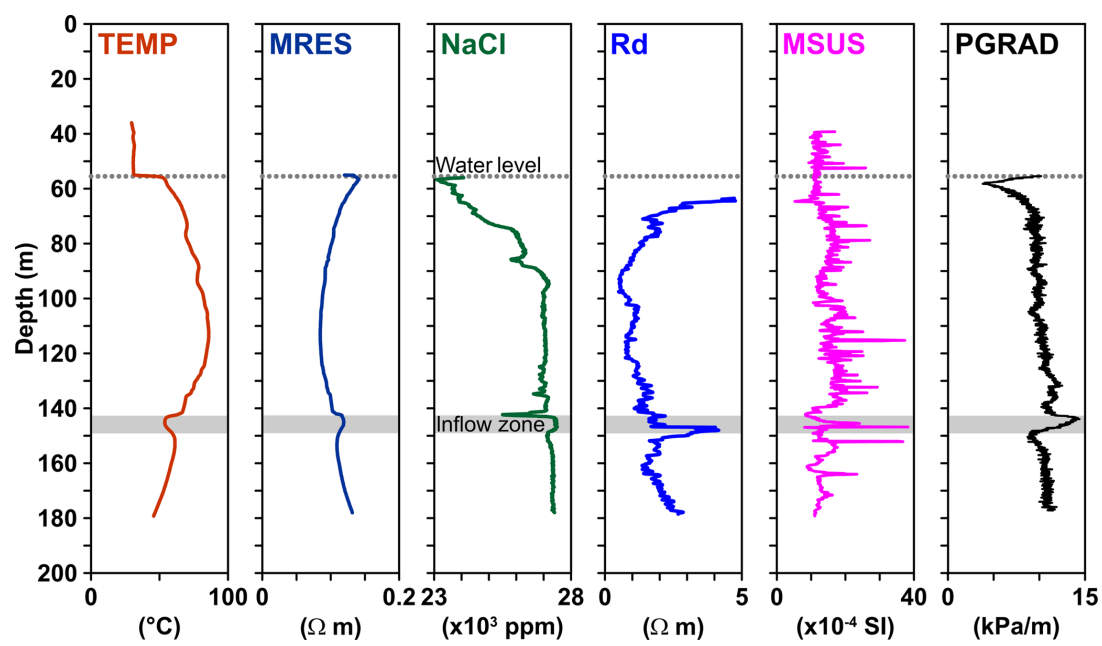

Figure 7. Selected results of geophysical downhole logging, borehole SE-02b, showing temperature (TEMP), fluid resistivity (MRES), fluid salinity as derived from resistivity measurements $(\mathrm{NaCl})$, rock resistivity $(\mathrm{Rd})$, magnetic susceptibility (MSUS), and the fluid pressure vertical gradient (PGRAD) as derived from the measured fluid pressure (not shown) (following Weisenberger et al., 2019).

son, 2009). The results will describe the deep volcanic edifice and pre-eruptive seafloor, the onset of explosive fragmentation at depth, and the possible explosive recycling of tephra (Schipper and White, 2016) in subaerial and submarine environments.

\section{Downhole temperature monitoring and fluid sampling}

The maximum temperature in borehole SE-01 in 2017 before the initiation of SUSTAIN drilling, $124^{\circ} \mathrm{C}$, occurred at $100-105 \mathrm{~m}$ measured depth (Fig. 3b), the same depth as the hydrothermal maximum in $1980,141^{\circ} \mathrm{C}$ (Jakobsson and Moore, 1982). Although the submarine temperature distribution has not substantially changed shape over the intervening 38 years, the temperatures in the subaerial tuff cone show marked decreases (Figs. 1c, 2b).

Borehole measurements undertaken 6 days after completion of SE-03 drilling indicated temperatures of $56-61{ }^{\circ} \mathrm{C}$ at $230-354 \mathrm{~m}$ measured depth below the ground surface (or 130-232 m b.s.1.) (Fig. 2c) (Weisenberger et al., 2019). Measurements made in summer 2018 gave similar results. This suggests that borehole fluids rapidly approached pre-drilling temperatures in September 2017. These temperatures are higher than the $20-30^{\circ} \mathrm{C}$ measured in 1964 in marine sedimentary rocks at $200-300 \mathrm{~m}$ depth in a borehole on Heimaey, the largest of the islands forming the archipelago (Tómasson, 1967; Hafstað et al., 2002) (Fig. 1). The lithified tephra of the Surtsey diatreme has not apparently reached thermal equilibrium with the surrounding seafloor sedimentary rocks 50 years after volcanic activity terminated.

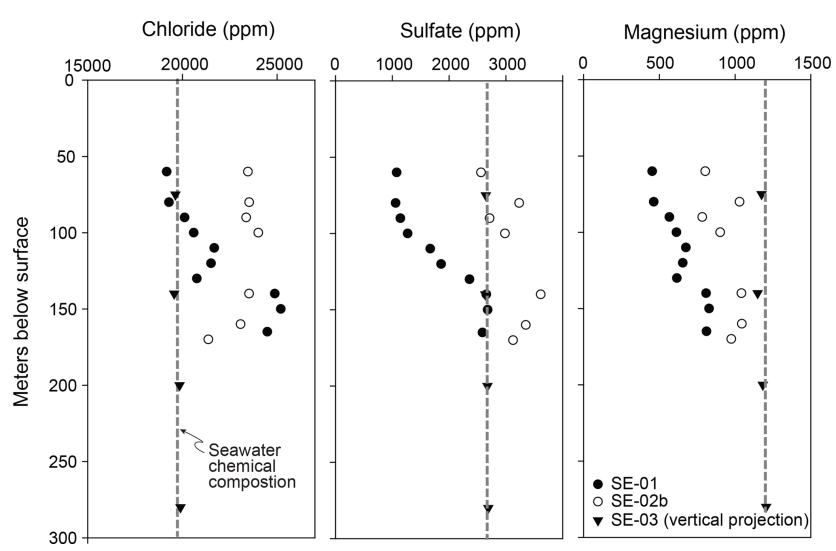

Figure 8. Compositions of fluids sampled from the SE-01, SE-02b, and SE-03 boreholes in September 2017.

Fluid sampling for geochemical and microbiological analyses used a slick line to mechanically open and close a $1 \mathrm{~L}$ fluid bailer at the sampling depth. Fluids sampled 1-3 weeks after the termination of drilling in September 2017 indicate that hydrothermal waters in the SE-01 borehole represent modified seawater typical of that involved in hydrothermal alteration of oceanic crust by leaching of basaltic rock and glass (Staudigel, 2004), followed by formation of secondary minerals, for example, anhydrite and Mg-containing phases (Fig. 8). The SE-02b and SE-03 borehole fluids, however, record the influences of the seawater drilling fluid.

\section{Geophysical logging, vertical borehole SE-02b}

Downhole geophysical logging, carried out by the ICDP Operational Support Group, used a $600 \mathrm{~m}$ logging winch and 
several sondes to measure fluid conductivity, temperature and pressure, magnetic susceptibility, electrical resistivity, fluid conductivity, natural gamma, and spontaneous potential to $180 \mathrm{~m}$ measured depth in borehole SE-02b (Fig. 7) (Weisenberger et al., 2019). To prevent collapse in the uppermost fractured tuff and to protect the logging sondes, the drill string remained in place to $39 \mathrm{~m}$. Figure 7 shows a selection of these soundings and two derived parameters, the fluid salinity $(\mathrm{NaCl})$ and the vertical pressure gradient (PGRAD). The measured fluid resistivity (MRES) of $0.1-0.14 \Omega \cdot \mathrm{m}$ is typical for seawater $(0.1-1 \Omega \cdot \mathrm{m})$, and variations closely follow the shape of the fluid temperature (TEMP) curve, as expected. The fluid salinity $(\mathrm{NaCl})$ shows a near-constant value of $27 \mathrm{ppt} \mathrm{NaCl}$ below $90 \mathrm{~m}$ yet decreases towards the zone of tidal flux, indicating a transition towards less saline water in the uppermost part of the water column. SE-02b borehole fluids sampled in September 2017, 3 weeks after completion of drilling (Fig. 7), also show lower chloride concentrations above $90 \mathrm{~m}$. The fluid samples from the SE-01 borehole, however, show a more pronounced decrease in chloride concentration from 55 to $90 \mathrm{~m}$ (Fig. 7). This suggests that the meteoric water-seawater zone (Ólafsson and Jakobsson, 2009) was not strongly disrupted by seawater circulating fluid during drilling. Rock resistivity (Rd) shows very low values $(0.5-5 \Omega \cdot \mathrm{m})$, similar to the range of fluid resistivity values. The shape of the MRES curve is closely reflected in the shape of the Rd curve and yields a correlation coefficient of $\approx 0.8$. This indicates highly permeable rock flushed with seawater (or a mixture of seawater and meteoric water). The relative increase in chloride, sulfate, and magnesium concentrations in fluid samples from the 1979 SE-01 borehole to the freshly drilled SE-02b borehole also indicates that the Rd and MRES values are influenced by residual seawater circulating fluid. The maximum temperature, $85.9^{\circ} \mathrm{C}$ at $113 \mathrm{~m}$, is almost $35^{\circ} \mathrm{C}$ lower than the temperature measured in the SE-01 borehole at the same depth before the onset of drilling, 119$122^{\circ} \mathrm{C}$. This suggests that the observed SE-02b temperature decrease mainly reflects cooling from seawater circulating fluid during drilling. By contrast, pronounced local deviations between 143-150 m measured depth below the ground surface in several logs (TEMP, MRES, Rd), the derived salinity $(\mathrm{NaCl})$, and the vertical pressure gradient (PGRAD) suggest an inflow zone where cooler water of higher salinity enters the borehole. These measurements correlate with deep porous layers identified in the 1979 drill core, which were inferred to channel the flow of cold seawater into the hydrothermal system (Jakobsson and Moore, 1982, 1986; Ólafsson and Jakobsson, 2009). The inflow of cooler water plays a role in recharging the system; it is heated as it percolates through the higher temperature rocks of the geothermal reservoir. Whole-rock compositional analyses of tuff samples from the 1979 SE-01 core show large decreases in $\mathrm{CaO}$ and $\mathrm{K}_{2} \mathrm{O}$ and increases in $\mathrm{MgO}$ and $\mathrm{Na}_{2} \mathrm{O}$ (Fig. 4), suggesting that the fluid flow pattern was established early in the life of the volcano. Increased chloride, sulfate, and magnesium in
2017 SE-01 fluid compositions (Fig. 8) in this zone indicate that the flow pattern has continued to the present time. Magnetic susceptibility ( $\chi_{\text {bulk }}$ ) in 2017 core reference samples increases in the zone of strongly hydrothermally altered tuff, $110-138 \mathrm{~m}$; sharply decreases in the inflow zone at $148 \mathrm{~m}$; increases slightly in the deeper zone of poorly consolidated tuff; and then decreases at $180 \mathrm{~m}$ measured depth. Dry density increases and water sorption decreases at $148 \mathrm{~m}$ measured depth (Fig. 3, Supplement Tables S1, S2).

\section{Microbiological investigations}

Fifty-six core samples for microbial detection and analysis were immediately fixed and frozen on-site. A $30 \mathrm{~cm}$ section was cut from the midsection of every third $3 \mathrm{~m}$ core run at the drill site and divided into three subsections: $10 \mathrm{~cm}$ for molecular analyses (MA), $8 \mathrm{~cm}$ for cultivation $(\mathrm{Cu})$, and $2 \mathrm{~cm}$ for microscopic investigation (M) (Weisenberger et al., 2019). MA sections were kept in the plastic core liner, wrapped in plastic, and kept in liquid nitrogen $\left(-196^{\circ} \mathrm{C}\right)$ until delivery to long-term laboratory storage at $-80^{\circ} \mathrm{C}$. $\mathrm{Cu}$ sections were immediately removed from the liner; placed in a sterile plastic bag, with oxygen removed; and stored at $4{ }^{\circ} \mathrm{C}$. M sections were incubated in a solution of $1 \times$ phosphate buffer solution (PBS) and $2 \%$ formaldehyde, washed twice with PBS 1X, transferred to a solution of PBS $1 \mathrm{X}$ and $96 \%$ ethanol, and stored at $-80^{\circ} \mathrm{C}$. To detect microbial contaminants introduced during drilling, circulating fluid was collected at each core sample depth and passed through a Sterivex filter to retain the microbial fraction. Samples were stored in liquid nitrogen at $-196^{\circ} \mathrm{C}$ on-site and then transferred to laboratory storage at $-80^{\circ} \mathrm{C}$ for future molecular analyses.

Preliminary investigations of the diversity, metabolism, and function of cultivated and non-cultivated microbes in SE-01 borehole fluids revealed the presence of thermophilic bacteria and archaea (Marteinsson et al., 2015). The 2017 core samples are now being enriched in diverse media for autotrophic methane, iron, and sulfur metabolisms and heterotrophic microorganisms at 22,60 , and $80^{\circ} \mathrm{C}$. Some enrichments show microbial growth. For example, eight different bacterial strains have been isolated and identified from a SE-02a sample at $15 \mathrm{~m}$ measured depth. At least one bacterial strain has been isolated at $80^{\circ} \mathrm{C}$ from a SE-02b sample at $180 \mathrm{~m}$. In addition to this cultivation-dependent approach, analyses using high-throughput amplicon sequencing, functional metagenomics, and metatranscriptomic analysis will be performed, and interactions between minerals and microorganisms will be studied with fluorescent in situ hybridization. 


\section{Magnetic, material, and geochemical characteristics of Surtsey basalt}

Thirty-three reference samples were collected from the SE02b and SE-03 cores, adjacent to the samples acquired for microbiological and fluid geochemical analyses, and distributed to science team members for collaborative, interdisciplinary investigations. Initial comparisons of the lapilli tuff from the time-lapse drill cores reveal that geochemical, mineralogical, and material changes have occurred from 1979 to 2017 (Figs. 2-4, Tables S1-S3). Dissolution and alteration of glass, plagioclase, and olivine since 1979 (Jakobsson and Moore, 1986) have produced additional smectitic clay mineral, principally nontronite, and authigenic zeolite and Al-tobermorite form complex surface textures. Dry density measured in 2017 shows slightly higher values overall compared with measurements by Oddsson (1982) (Fig. 3), possibly through the growth of mineral cements that fill vesicles and interstitial voids. Lapilli tuff density is higher overall in the sub-seafloor diatreme. Water absorption measured in 2017 (ASTM C97M-18) shows higher values, 8-20 wt \%, than those obtained in 1979 measurements, in which samples were not oven-dried (Jakobsson and Moore, 1982). Even so, the pronounced increase at higher temperatures of the submarine hydrothermal zone, at $92-138 \mathrm{~m}$ measured depth below the ground surface, suggests progressive alteration of basaltic glass to expansive smectitic clay mineral. Wholerock major element X-ray fluorescence analyses compare the compositions of archived 1979 core samples and the 2017 SE-02b reference samples. These confirm that geochemical changes have accompanied glass and mineral alteration processes (Fig. 4, Table S3). Decrease in $\mathrm{CaO}$ at $90-140 \mathrm{~m}$ results from dissolution of glass, as well as dissolution of labradorite crystals in this zone. $\mathrm{As} \mathrm{Na}_{2} \mathrm{O}$ increases, $\mathrm{K}_{2} \mathrm{O}$ decreases. This may result from dissolution of glass and abundant precipitation of analcime in the submarine hydrothermal system, as well as alteration of early-formed phillipsite to analcime.

Measurements of the natural remanent magnetization (NRM) of the lapilli tuff reference samples vary from approximately 0.1 to $3.0 \mathrm{~A} \mathrm{~m}^{-1}$ (Fig. 3, Table S2). Remanence intensity increases with depth. It is typically higher in the hydrothermally altered submarine lapilli tuff than in the somewhat glassy, lapilli tuff above sea level and the inflow zone at $148 \mathrm{~m}$ measured depth. NRM is by far the highest in the basaltic intrusion at the base of the SE-03 borehole. Measurements of bulk magnetic susceptibility ( $\chi_{\text {bulk }}$ ) (Table S2) show a similar trend, also recorded in the SE-Ob geophysical $\log$ (Fig. 7). Bulk magnetic susceptibility (values obtained using SI units) varies from approximately $6-11 \times 10^{-4}$ in the still glassy lapilli tuff above sea level, to $7-16 \times 10^{-4}$ in the more altered submarine lapilli tuff at the hydrothermal temperature maxima (65-138 m measured depth), to $7-10 \times 10^{-4}$ in the less altered lapilli tuff at the base of the SE-02b borehole (148-180 m measured depth), and to $8-23 \times 10^{-4}$ in the lapilli tuff of the deeper diatreme traversed by the SE03 borehole (Fig. 3). The lowermost sample, a basaltic intrusion, has an exceptionally high bulk magnetic susceptibility, approximately $116 \times 10^{-4}$. Frequency-dependent magnetic susceptibility $\left(\chi_{\mathrm{fd}}\right)$ varies between $2 \%$ and $6 \%$ and indicates the presence of superparamagnetic grains, $<20 \mathrm{~nm}$ for titanomagnetites and their partial oxidation products. Magnetite particles of this physical size carry no magnetic remanence but are typical of authigenic, diagenetic and biogenic alteration processes in marine lavas and sediments (e.g., Lovley et al., 1987; Jackson and Swanson-Hysell, 2012; Roberts, 2015). Variations in the abundance of superparamagnetic grains therefore may provide indications of fluid-microbialbasalt interactions.

\section{Significance of time-lapse drilling on Surtsey}

The 1979 and 2017 drilling projects at Surtsey volcano provide a record of global significance for studying the mechanics of submarine and emergent basaltic eruptions, the deep structure of young oceanic islands in shallow rift-zone environments, and the processes of tephra lithification that create the resistance of emerging islands to incessant marine erosion. The time-lapse drill cores precisely record the progression of hydrothermal alteration, the rapid evolution of magnetic properties, the diverse processes of glass dissolution and alteration, and the cycling of authigenic mineral cements and their influences on the material and physical properties of young basalt. Integrated investigations of the drill cores, hydrothermal fluid investigations, and incubation experiments in the Surtsey subsurface observatory are expected to provide foundational references for the initiation of microbial life in a pristine basaltic habitat, as well as the systematic, longitudinal characterization of water-microbial-basalt interactions in subaerial and submarine environments.

Data availability. Scientific data sets of the 2017 Surtsey Underwater volcanic System for Thermophiles, Alteration processes and INnovative concretes (SUSTAIN) drilling project at Surtsey volcano, Iceland, are available at GFZ Data Services, https://doi.org/10.5880/ICDP.5059.001.

Sample availability. Drill core samples are stored at the Icelandic Institute for Natural History (Náttúrufræðistofnun Íslands) Urriðaholtsstræti 6-8, 210, Garðabær, Iceland. Each IGSN number represents the sample set of the corresponding Surtsey borehole, for example, http://igsn.org/ICDP5059EHS2001. These are SE-1 (Hole ID:73552), CDP5059EHS2001; SE2a (Hole ID:73553), ICDP5059EHT2001; SE-2b (Hole ID:73554), ICDP5059EHY2001; and SE-3 (Hole ID:73555), ICDP5059EHU2001. 
Supplement. The supplement related to this article is available online at: https://doi.org/10.5194/sd-25-35-2019-supplement.

Author contributions. MDJ and MTG led the project. MDJ, MTG, SLJ, AS, VTM, WB, BZ, PC, JMR, JGM, JDLW, KJ, TBW, and $\mathrm{JMcP}$ formulated the project and acquired the funding. TBW, JMR, AS, BIK, VTM, AB, PB, SC, CFG, CG, ÁG, ÁTG, CH, KJ, SSJ, SLJ, AMK, BM, EM, JMcP, ESO, SP, SLO, SP, SPS, AT, JDLW, MTG, and MDJ performed on-site work and analyses. JK, MG, TBW, AMK, VTM, SSJ, BM, and MTG performed downhole logging. BM was the on-site drilling supervisor. AS, BIK, TBW, VTM, and AMK sampled borehole fluids. TBW, JMR, AB, PB, JGB, SC, MFF, CFG, CG, CH, KJ, AMK, SLJ, EM, JM, SLO, VP, SP, AT, JDLW, and MDJ logged the core. MDJ, PCL, and JMM measured rock physical properties. JMR, JGB, PGC, and MDJ performed solid rock geochemical and mineralogical analyses while AS, AMK, and BIK carried out fluid geochemical analyses. PB, VTM, AMK, PV, and SLJ performed microbiological analyses. KJ is the core curator. MDJ, MTG, TBW, JMR, AS, BIK, HIR, VTM, PV, PB, CFG, TH, SLJ, JGM, AT, and JDLW wrote the paper with contributions from all authors.

Competing interests. The authors declare that they have no conflict of interest.

Disclaimer. Any use of trade, firm, or product names is for descriptive purposes only and does not imply endorsement by the U.S. Government.

Acknowledgements. Funding for this project was provided by the International Continental Scientific Drilling Program (ICDP) through a grant to the SUSTAIN project (led by Marie D. Jackson); a grant of excellence from the Icelandic Research Fund, ICFRANNÍS (the IceSUSTAIN consortium led by Magnús T. Gudmundsson); the Bergen Research Foundation and K.G. Jebsen Centre for Deep Sea Research at the University of Bergen, Norway (led by Steffen Leth Jørgensen); the German Research Foundation (DFG) (led by Wolfgang Bach and Bernd Zimanowski); and DiSTAR, Federico II, University of Naples, Federico II, Italy (led by Piergiulio Cappelletti). The University of Utah, USA (Marie D. Jackson), and the two Icelandic power companies Reykjavík Energy and Landsvirkjun contributed additional funds. In kind support by several Icelandic institutions and companies contributed greatly to the success of the project, as did the dedicated work of several volunteers. The logistical support provided by the Icelandic Coast Guard was instrumental in carrying out the drilling operation. Norðurflug Helicopters and the Vestmannaeyjar Rescue Group provided critical logistical support. Jeremy Fisher and Rowan McGuire contributed to this article. The DOSECC drilling team, Steve Cole, Justin Blouin, A. J. Vecchiarelli, Matthew Lyon, and Michael Vinson, did excellent work. Hjalti Franzson provided guidance, and Porsteinn Jónsson, Bjarni Kristinsson, Gísli Sighvatsson, and Sveinbjörn Steinpórsson contributed to the logistical operation on Surtsey. Unpublished borehole temperature measurements were made during the annual Surtsey Research Society expedition in July 2018.

Review statement. This paper was edited by Thomas Wiersberg and reviewed by Karoly Nemeth and Martin Jutzeler.

\section{References}

Adkins, S.: Volcanic cores from Iceland's youngest island, Coring Magazine, 6, 38-39, 2018.

Alexandersson, T.: The sedimentary xenoliths from Surtsey: turbidites indicating shelf growth, Surtsey Res. Progr. Rept., 6, 101$116,1972$.

ASTM C97/C97M-18: Standard Test Methods for Absorption and Bulk Specific Gravity of Dimension Stone, ASTM International, West Conshohocken, PA, https://doi.org/10.1520/C0097_C0097M-18, 2018.

Baldursson, S. and Ingadóttir, Á.: Nomination of Surtsey for the UNESCO World Heritage List, Icelandic Institute of Natural History, Reykjavik, 2007.

Einarsson, P.: Plate boundaries, rifts and transforms in Iceland, Jökull, 58, 35-58, 2008.

Hafstað, P. H., Jónasson, P., and Hjaltadóttir, S.: Vestmannaeyjar. Borholur á Heimey og mælingar á peim (in Icelandic), Vestmannaeyjar, Measurements in boreholes on Heimaey, Orkustofnun, Greinargerð РP-PJ-SHj-2002/13, 19 pp., 2002.

Jackson, M. and Swanson-Hysell, N. L.: Rock magnetism of remagnetized carbonate rocks: Another look, in: Remagnetization and Chemical Alteration of Sedimentary Rocks, edited by: Elmore, R. D., Muxworthy, A. R., Aldana, M. M., and Mena, M., Geological Society of London Special Publication, 371, 279-303, https://doi.org/10.1144/SP371.3, 2012.

Jackson, M. D., Gudmundsson, M. T., Bach, W., Cappelletti, P., Coleman, N. J., Ivarsson, M., Jónasson, K., Jørgensen, S. L., Marteinsson, V., McPhie, J., Moore, J. G., Nielson, D., Rhodes, J. M., Rispoli, C., Schiffman, P., Stefánsson, A., Türke, A., Vanorio, T., Weisenberger, T. B., White, J. D. L., Zierenberg, R., and Zimanowski, B.: Time-lapse characterization of hydrothermal seawater and microbial interactions with basaltic tephra at Surtsey Volcano, Sci. Dril., 20, 51-58, https://doi.org/10.5194/sd-20-51-2015, 2015.

Jakobsson, S. P.: Dredge hauls from Vestmannaeyjagrunn, Iceland, Surtsey Res. Progr. Rept., 9, 142-148, 1982.

Jakobsson, S. P.: Geological map of Surtsey, scale $1: 5000$, Icelandic Institute of Natural History and the Surtsey Research Society, Reykjavík, 2000.

Jakobsson, S. P. and Moore, J. G.: The Surtsey research drilling project of 1979, Surtsey Res. Progr. Rept., 9, 76-93, 1982.

Jakobsson, S. P. and Moore, J. G.: Hydrothermal minerals and alteration rates at Surtsey volcano, Iceland, Geol. Soc. Am. Bull., 97, 648-659, 1986.

Jakobsson, S. P., Gudmundsson, G., and Moore, J. G.: Geological monitoring of Surtsey, Iceland, 1967-1998, Surtsey Research, 11, 99-108, 2000.

Jakobsson, S. P., Thors, K., Vésteinsson, Á. T., and Ásbjörnsdóttir, L.: Some aspects of the seafloor morphology at Surtsey vol- 
cano: the new multibeam bathymetric survey of 2007, Surtsey Research, 12, 9-20, 2009.

Kokelaar, B. P.: The mechanism of Surtseyan volcanism, J. Geological Society of London, 140, 939-944, 1983.

Lovley, D. R., Stolz, J. F., Nord Jr., L., and Phillips, E. J. P.: Anaerobic production of magnetite by a dissimulatory iron-reducing microorganism, Nature, 330, 252-254, 1987.

Magnússon, B., Magnússon, S. H., Ólafsson, E., and Sigurdsson, B. D.: Plant colonization, succession and ecosystem development on Surtsey with reference to neighbouring islands, Biogeosciences, 11, 5521-5537, https://doi.org/10.5194/bg-115521-2014, 2014.

Marteinsson, V., Klonowski, A., Reynisson, E., Vannier, P., Sigurdsson, B. D., and Ólafsson, M.: Microbial colonization in diverse surface soil types in Surtsey and diversity analysis of its subsurface microbiota, Biogeosciences, 12, 1191-1203, https://doi.org/10.5194/bg-12-1191-2015, 2015.

Moore, J. G.: Structure and eruptive mechanisms at Surtsey Volcano, Iceland, Geol. Magazine, 122, 649-661, 1985.

Oddsson, B.: Rock quality designation and drilling rate correlated with lithology and degree of alteration in volcanic rocks from the Surtsey 1979 drill hole, Surtsey Res. Prog. Rept., 9, 94-97, 1982.

Ólafsson, M. and Jakobsson, S. P.: Chemical composition of hydrothermal water and water-rock interactions on Surtsey volcanic island: A preliminary report, Surtsey Research, 12, 29-38, 2009.

Reynisson, R. F. and Jakobsson, S. P.: Xenoliths of exotic origin at Surtsey volcano, Iceland, Surtsey Research, 12, 21-27, 2009.

Rhodes, J. M. and Vollinger, M. J.: Composition of basaltic lavas sampled by phase-2 of the Hawaii Scientific Drilling Project: Geochemical stratigraphy and magma types, Geochem. Geophy. Geosy., 5, Q03G13, https://doi.org/10.1029/2002GC000434, 2004.

Roberts, A. P.: Magnetic mineral diagenesis, Earth Science Reviews, 151, 1-47, 2015.

Santelli, C. M., Orcutt, B. N., Banning, E., Bach, W., Moyer, C. L., Sogin, M. L., Staudigel, H., and Edwards, K. J.: Abundance and diversity of microbial life in ocean crust, Nature, 453, 653-656, 2008.

Schipper, C. I. and White, J. D. L.: Magma-slurry interaction in Surtseyan eruptions, Geology, 44, 195-198, 2016.

Schipper, C. I., Jakobsson, S. P., White, J. D. L., Palin, J. M., and Bush-Marcinowski, T.: The Surtsey magma series, Sci.-Rep.UK, 5, 11498, https://doi.org/10.1038/srep11498, 2015.
Schipper C. I., Le Voyer, M., Moussallam, Y., White, J. D. L., Thordarson, T., Kimura, J.-I., and Chang, Q.: Degassing and magma mixing during the eruption of Surtsey Volcano (Iceland, 19631967): the signatures of a dynamic and discrete rift propagation event, Bull. Volcanol., 78, 1-19, 2016.

Staudigel, H.: Hydrothermal alteration processes in the oceanic crust. Treatise on geochemistry, edited by: Holland, H. D. and Turekian, K. K., 511-535, Amsterdam, Boston, ElsevierPergamon, 2004.

Thórarinsson, S.: Surtsey, The New Island in the North Atlantic, The Viking Press, New York, 1967.

Thórarinsson, S.: Sídustu thaettir Eyjaelda (English summary: The last phases of the Surtsey eruption), Náttúrufraedingurinn, 38, 113-135, 1969.

Thórarinsson, S., Einarsson, Th., Sigvaldason, G., and Elísson, G.: The submarine eruption off the Vestmann Islands 1963-64, Bull. Volcanol., 29, 435-455, 1964.

Thors, K. and Jakobsson, S. P.: Two seismic reflection profiles from the vicinity of Surtsey, Iceland, Surtsey Res. Progr. Rept. 9, 149$151,1982$.

Tómasson, J.: On the origin of sedimentary water beneath Vestmann Islands, Jökull, 17, 300-311, 1967.

Türke, A. T., Jackson, M. D., Bach, W., Kahl, W.-A., Gudmundsson, M. T., and Jørgensen, S. L.: Design of the Subsurface Observatory at Surtsey Volcano, Iceland, Sci. Dril., in press, 2019.

Weisenberger, T. B., Gudmundsson, M. T., Jackson, M. D., Gorny, C., Türke, A., Kleine, B. I., Marshall, B., Jørgensen, S. L., Marteinsson, V. P., Stefánsson, A., White, J. D. L., Barich, A., Bergsten, P., Bryce, J., Couper, S., Fahnestock, F., Franzson, H., Grimaldi, C., Groh, M., Guðmundsson, Á., , Gunnlaugsson Á. P., Hamlin, C., Högnadóttir, P., Jónasson, K., Jónsson, S. S., Klonowski, A., Kück, J., Magnússon, R. L., Massey, E., McPhie, J., Ólafsson, E. S., Onstad, S. L., Prause, S., Perez, V., Rhodes, J. M., and Snorrason, S. P.: Operational Report for the 2017 Surtsey Underwater volcanic System for Thermophiles, Alteration processes and INnovative Concretes (SUSTAIN) drilling project at Surtsey Volcano, Iceland, Geo Forschungs Zentrum (GFZ) German Research Centre for Geosciences, https://doi.org/10.2312/ICDP.5059.001, 2019.

White, J. D. L. and Ross, P.-S.: Maar-diatreme volcanoes: A review, J. Volc. Geotherm. Res., 201, 1-29, 2011.

Witke, A.: Iceland drilling project aims to unearth how islands form, Nature, 547, 387-388, 2017. 